\title{
Bargaining Power at the Negotiation Table and Beyond
}

\author{
Shaina D. Western ${ }^{1}$ \\ University of Edinburgh, 15a George Square, Edinburgh EH8 9LD, Scotland \\ swestern@ed.ac.uk
}

Received 4 September 2018; accepted 29 June 2019

\begin{abstract}
International treaties require ratification to go into effect. But while some treaties have high ratification rates, many do not, leading to a system where issues appear to be addressed on paper but are not in practice. This article seeks to address why treaties receive varying levels of support and finds that factors present during the negotiation phase of the agreement affect the ratification phase. Specifically, bargaining power at and away from the negotiation table influences both the substantive nature of the treaty and the extent to which it will be widely ratifiable. This article explores this issue both in a statistical analysis and in two pairs of qualitative case studies. The evidence indicates that negotiation processes cast a long shadow on the fate of international agreements leading to the current treaty system of prolific international law that is not ratified by most states.
\end{abstract}

\section{Keywords}

treaty ratification - bargaining power - small states - mixed methods

1 Shaina D. Western is a lecturer in international relations and quantitative methods at the University of Edinburgh. She has published in journals such as the British Journal of Political Science and International Studies Quarterly. Among her research interests are treaty ratification, international negotiations and migrant rights. I would like thank Jeannette Money, Josephine Andrews, Heather Elko McKibben and Richard A.I. Johnson. 
Whether actors reach an agreement at the bargaining table often defines whether a negotiation was a success or a failure (Song \& Whittington 2004). ${ }^{2}$ To understand these different negotiation outcomes, one strand of the academic literature starts with agreements that have come into fruition to understand why and how actors reach the agreement that they did (Odell 200o). Another strand of literature focuses on negotiation processes that have deadlocked (Narlikar 2010; Odell 2009), broken down (Putnam 1988) or never got off the ground (Dimitrov et al. 2007). Yet this dichotomous view of negotiation that focuses on whether a negotiated agreement is reached masks a more complex picture of how illusive cooperation can be. In particular, international treaties require ratification to become legally binding. Thus, it is insufficient for a state to agree to a deal at the negotiation table; it must also be ratified at the domestic level for it to go into effect. This pressure shapes the bargaining process (Putnam 1988). The ratification rate crucially determines (1) whether a treaty will go into effect and (2) the number of states to which the treaty provisions will apply. ${ }^{3}$ While widespread ratification is not sufficient for an agreement to be successful, sparse ratification can doom it to failure. Most treaties, however, are not widely ratified (von Stein 2018).

Currently there is a disjuncture between the view of ratification in the literature and what ratification patterns look like in practice. Specifically, there is a wealth of academic literature on why states ratify treaties that focuses on the adoption of widely ratified treaties. Yet these treaties are relatively rare, as many treaties are sparsely ratified (von Stein 2018). This selection bias is problematic for understanding ratification more broadly because the reasons these treaties are ratified may not be applicable to less well-ratified treaties (Western et al. 2019). One critical reason why states ratify treaties is because

2 Song and Whittington (2004) do note that there are problems with this definition of success as treaties may be created, but do not fundamentally resolve the problem. Underdal (1983) notes that failing to reach an agreement may not be considered failure of the negotiation process if the negotiations moved the issue forward. He rather focuses on whether an agreement is short of the Pareto frontier or if the agreement comes at too high a cost as outcomes that can also be considered failure. Bargaining success, alternatively, is framed as the extent to which a state attains its preferences in a negotiation (Weiler 2012). However, here too, attaining preferences necessitates that the treaty ultimately ends with a successful agreement that does encapsulate preferences.

3 I use the term ratification to capture ratification, accession, and approval as they are similar in the degree to which they are legally binding. Thus, ratification rate is a combination of all of these methods of approval. 
they agree with the content and purpose of the treaty (Simmons 2009). Yet this answer does not address why and how so many treaties exist that so few states see as being in their interests to ratify. Similarly, others find that states are more likely to ratify treaties that have widespread support in the international community (Goodliffe \& Hawkins 2006; Wotipka \& Tsutsui 2008), and specifically from well-informed states (Hugh-Jones, Milewicz \& Ward 2016). This literature, however, does not shed light on why treaties fail to generate this type of support in the first place. ${ }^{4}$ Additionally, this literature finds support for factors that vary across states, but do not vary across agreements. ${ }^{5}$ Relatedly, a large strand of this literature presumes that states promoting international laws have the ability to incentivize others to ratify, which is not is always the case. ${ }^{6}$ Finally, from a methodological perspective, this literature relies on techniques that are not as useful when very few states have ratified, as there simply is not much information about what promotes ratification for poorly ratified treaties. ${ }^{7}$

I argue that the origins of variation in the ratification rate stem from the negotiation processes themselves. Thus, ratification rate is a byproduct of the negotiation process and, indeed, for a negotiation to be successful in the grand scheme it must be widely ratified. This interplay between the negotiation phase and the ratification phase needs to be addressed if we are to understand what makes negotiations successful.

4 While some scholars have studied why these virtuous cycles take off (Risse, Ropp \& Sikink et al. 1999; Risse, Ropp \& Sikkink 2013; Finnemore \& Sikkink 1998), much less focus is given on why normative claims fail.

5 This literature argues that states are more likely to ratify because domestic institutions make commitment costs fairly minimal, either because the state is compliant or because the treaty is unlikely to be enforced against the state (Cole 2005; Chapman \& Chaudoin 2013; Hill 2016). Relatedly, this literature finds that the institutional contexts in which states are embedded, most critically the legal system (Simmons 20o9), influence the propensity of states to commit.

6 This literature argues that states ratify to appease international audiences (Smith-Cannoy 2012; Milewicz \& Elsig 2014) and to attract foreign aid (Wotipka \& Tsutsui 2008; Spence 2014; Nielsen \& Simmons 2015) yet not all states have the resources to pursue this strategy.

7 Models of treaty ratification assume that eventually all states will ratify the treaty that is being studied (see Box-Steffensmeier \& Jones (2004) for further information on event history modeling). When only a handful of states ratify a treaty, it seems unlikely that this assumption holds. Moreover, when only a few states ratify, there is little information on which to base the risk of ratification, making it difficult to estimate statistical models. 


\section{Illustrating the Importance of Ratification Rate}

Negotiations over international law concerning outer space illustrate why variation in ratification is important to understand. In the 195os and 196os, the "space race" raised concerns over how international law would apply beyond earth. These concerns sparked the negotiation of an international treaty (Vlasic 1967). In 1966, the Soviet Union and the United States each proposed draft agreements, which were quickly reconciled (Vlasic 1967; Dembling \& Arons 1967). By December 1966, the General Assembly approved the draft now known as the 1967 Treaty on Principles Governing the Activities of States in the Exploration and Use of Outer Space, Including the Moon and Other Celestial Bodies (hereafter referred to as the "Outer Space Treaty"). Although the Outer Space Treaty improved the status quo for industrialized states, it disadvantaged states that lacked the technological and financial resources to create their own space programs. Shortly after the approval of the first draft, developing states pushed for a treaty that would stipulate common ownership over outer space so the exploitation of natural resources in space would benefit all mankind (Dembling \& Arons 1967; Mau 1984). Argentina introduced a draft treaty in the UN General Assembly in 1970 that stated that the moon belongs to mankind and hence that all states should benefit from its exploration. Years of contentious negotiations culminated with the 1979 Agreement Governing the Activities of States on the Moon and Other Celestial Bodies (hereafter referred to as the "Moon Treaty"). ${ }^{8}$

In both cases, the negotiation processes can be considered to be "successful" in that states reached a negotiated agreement. Indeed, in the latter case, this bargaining ostensibly is more impressive because developing states lacked a strong alternative to the agreement which the United States and Soviet Union had in the first case. They also convinced the United States and Soviet Union to support the res communis principle at the United Nations, which ostensibly would threaten these states' interests in developing space for commercial purposes (Christol 1985).

Nevertheless, the status of these two treaties in international law is markedly different due to variation in ratification (see Fig. 1). Many states quickly ratified the Outer Space Treaty and it went into effect within the year and prior to the moon landing (Jaksetic 1978; Vlasic 1967). In contrast, few states ratified

8 The difference between the two treaties is that the Outer Space Treaty stipulates that no state can claim ownership over territory, but whoever arrives at these resources is free to exploit them. In contrast, the universal definition in the Moon Treaty implies that, as a common resource, all states should reap the benefit of exploitation. 


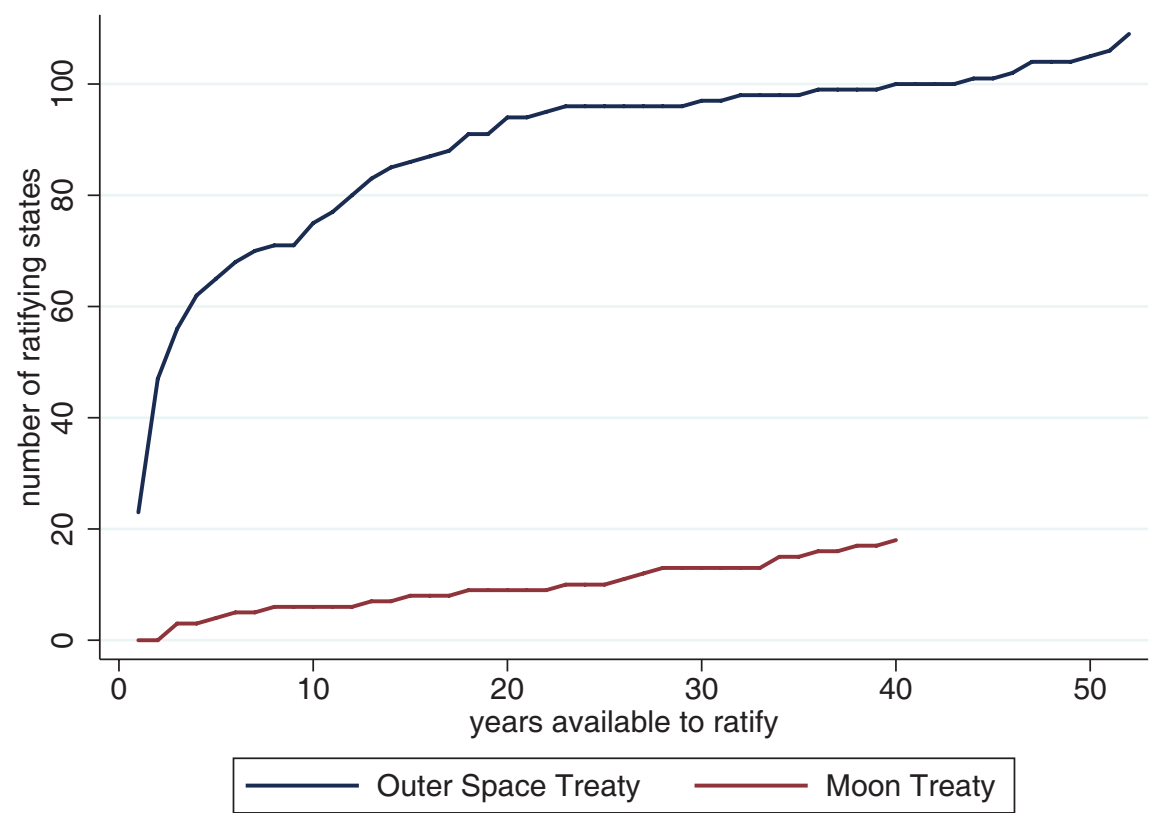

FIGURE 1 Number of ratifying states to the Outer Space Treaty and Moon Treaty

the Moon Treaty. Thus, while technically the Moon Treaty provides guidance as to how outer space resources could be used in the future, in reality, these principles are ineffectual as the states to whom they could apply are not legally bound (Christol 1985). Thus, the impressive concessions that developing states won at the bargaining table were illusory due to poor ratification even among states that ostensibly would have benefited from such provisions.

This example highlights the major factors that I argue explain variation in ratification. The first factor is that during the bargaining process, negotiations vary in how much consensus there is around different aspects of the treaty. In the Outer Space Treaty negotiations, while some states wanted the agreement to go further, there was a general consensus about the basic principles outlined in the treaty (Christol 1985). In contrast, during the Moon Treaty negotiations the United States begrudgingly accepted the res communis provisions at the table, but was not genuinely convinced, and, as such, could avoid making this commitment legally binding for itself (Christol 1985). The second factor is that the power of those spearheading the negotiation process varies considerably. In the Outer Space Treaty negotiations, the countries leading the negotiation had a significant amount of power and, as such, could create conditions necessary to encourage others to adopt the agreement. In contrast, during the Moon Treaty negotiations, the states leading the process had sufficient power 
to move the treaty through the bargaining process, but were left with a treaty that was poorly ratified. Thus, variation in ratification rate can be explained by factors that stem from the bargaining process. Consequently, while reaching an agreement at the negotiation table is necessary for an agreement to be successful, it is not sufficient; thus, studies of negotiations should consider the ratification phase as an alternative indicator of a negotiation's success.

This article proceeds as follows: I begin by reviewing the extant literature on the relationship between negotiations and ratification, focusing on how different forms of power likely influence ratification. In the second section, I present a statistical analysis of treaty ratification rate. I show that there is some support for the contestation that negotiations vary in the level of support within the bargaining phase and that this variation is highly related to the ratification phase. This evidence supports the contestation that among ostensibly successful negotiations there is significant variation in levels of support. Because the concepts that can be quantitatively measured from negotiations are necessarily abstract (Hopmann 2002), I conduct qualitative case studies on paired negotiations. In analyzing these negotiations there is support that there were substantial qualitative differences in the ways in which poorly-ratified and widely-ratified treaties are negotiated. I conclude with a discussion of the implications of this study for our understanding of international negotiations and treaties more generally.

\section{Literature Review and Theoretical Argument}

Treaty ratification is addressed in a literature of its own as well as in bargaining literature; in this section, I discuss the extent to which this literature can explain differences in ratification rate across agreements. The ratification literature often overlooks the treaty creation process in the ratification process. However, there are some notable exceptions that suggest that the negotiation process is important to understand the ratification phase. Elsig and Milewiscz (2017), for instance, find that states that participate in the treaty negotiation process are more likely to sign international agreements; thus, in some ways, the negotiation process binds negotiators to the agreements they help to create. Western et al. (2019) find that factors highlighted in the negotiation help to explain ratification.

The bargaining literature, in contrast, finds that ratification, and particularly threats of non-ratification, can influence the outcome of the negotiation. States that have ratification constraints generally have better positions at the bargaining table because they can move the agreement closer towards their 
ideal point because they can credibly argue that not conceding risks ratification failure (Schelling 1980; Putnam 1988; Dluhosch \& Ziegler 2011) Ratification constraints are determined by states' outside options which determine what outcomes to reject (Schelling 1980; Voeten 2001; McKibben 2015). The outside option is the outcome that will result from a no-deal situation. Conventional wisdom states that the less a state values an agreement - i.e. the more attractive the outside option is - the more power it has in a negotiation because it can coerce others into accepting a position closer to its preferences by threatening to walk away from the negotiation entirely (McKibben 2015). One factor that influences the outside option is the conditions necessary to satisfy key veto players in the other state such that the agreement can be ratified. Evidence of these outside options are seen in threats of non-ratification, which can feasibly lend a state increased bargaining power in a negotiation (Schelling 1980; Putnam 1988).

One problem, however, with applying these arguments to multilateral negotiations is that some of the assumptions underlying their effectiveness do not hold in a multilateral context. Multilateral treaties vary in the threshold that they require to go into effect and often such thresholds are comparatively low, such that an agreement can go into effect with low levels of ratification. States are able to create laws that incapsulate their preferences in international law with relatively little support in practice. Moreover, in multilateral negotiations "threats" of non-ratification are not always a strategy to move the treaty closer to their policy preferences, rather they are statements of fact. If reaching an agreement is valued more than the enforcement stage, treaties may make it through the negotiation process regardless of suspected low ratification potential.

If a state, or more specifically, any veto player within a state, prefers the status quo over a negotiated agreement then the state cannot credibly commit to ratify during the bargaining process. Consequently, threats that the treaty will not be ratified are ineffective if the other party believes that the state will not ratify the treaty regardless of whether concessions are made and if the treaty can be approved without their support. Under such circumstances, no agreement is the preferred outcome. Even here, states can have incentives to go to the bargaining table, however their unwillingness to concede will diminish their ability to get others to accept their position. ${ }^{9}$ Similarly, states that

9 There are several reasons why such states would bargain despite not wanting an agreement. First, if states seeking to change the status quo use normative-based arguments as part of the negotiation process, not participating could be seen as a violation of the norm and, therefore, states could have incentives to participate on such grounds (Panke 2015). Second, 
want to change the status quo and do not foresee that others will ratify can have incentives to push an agreement through the treaty creation process. In doing so, they intend to use their work at the international level to bolster their support domestically (Western et al. 2019). Thus, it is possible that some actors negotiate without foreseeing their own ratification. This conclusion is important because it suggests that ratification threats are weaker in multilateral negotiations and thus ratification threats reveal that a widely ratified treaty is not possible.

\section{Powering through Negotiations and Ratification}

Bargaining power is defined as the ability of states to successfully push for their position in a negotiation (Schneider 2011; Ramsay 2011). Although material power may influence bargaining power, the two terms are not synonymous as parties often can shape the outcome of a negotiation despite ostensibly having less material power. There are two predominant sources of bargaining power in a negotiation in addition to outside options: argumentation and institutional power. Yet, as I will show, while these sources of power may help shape and create an agreement, they have limited power beyond the bargaining table.

Argumentation allows states to debate and deliberate about the claims being made in a negotiation. There are two ways in which argumentation is a source of power. First, interests and identities are not fixed and by negotiating, actors are able to persuade others (Risse 2000). Argumentation is often a critical strategy for weaker parties in a negotiation because if they can convince more powerful states to change their perceptions of the issue, they can create an agreement closer to their own preferences. If these arguments can convince veto players, then argumentation can promote ratification. Second, argumentation can change which positions are possible to take at the negotiation table. Panke (2012) finds that small states use strategies in the argumentation process to "lock-in" a particular normative framework. When such strategies are used, objections to the materially weaker states' moral arguments seemingly violate

participation in the negotiation process can allow states to shape the content of the treaty and to express their preferences. Even if these preferences are not fully captured in the treaty itself, they may be able to persuade the states that do want the agreement to change the text from what they would have had if they were not present. Third, these states can seek to stall or delay the negotiation process. International institutions decrease the transaction costs of participating in a negotiation (Keohane 1984). These tactics may be useful in the short run to prevent a treaty, particularly one that the state does not like, from going into effect. At some point, the costs of such tactics are likely to increase to a point where states will prefer to relinquish sunk costs and end negotiations at the bargaining table. 
international norms and, as such, more powerful states cannot successfully push for their agenda.

Yet while argumentation may play a substantial role at the bargaining table, the degree to which argumentation changes outcomes in the ratification stage is debatable. A cynical view of argumentation is that supposed "shifts" and "consensus" are not genuine. Just because negotiators accept a particular argument in a negotiation does not necessarily mean that they are convinced, but rather they no longer are willing to bear the costs of debating the point. Moreover, the "lock-in" strategies that Panke (2012) details are likely to be less useful in the ratification stage as actors do not necessarily need to counter normative claims in the ratification phase as they can simply keep an issue off of the agenda. A more generous view of the role of argumentation leads to the same theoretical expectations. Negotiators themselves may find arguments compelling at the negotiation table but they might not be able to convince others in the domestic ratification process.

An important implication of the logic of argumentation is that there is variation in the extent to which arguments are compelling and, thus, there is variation in the support built into the agreement. When more actors are genuinely convinced during the negotiation to accept the positions incapsulated in the treaty, such agreements are more likely to result in widespread ratification. In contrast, when fewer negotiators are convinced during the negotiation phase, that variation should manifest in poor ratification rates. Thus, the support built in the agreement by negotiators is likely to influence ratification rate.

Hypothesis 1: Treaties that gain more consensus during the negotiation phase are more likely to be widely ratified than those treaties that do not gain wide-spread support.

Institutional power is also a significant source of power in most international negotiations. Small states, in particular, often have a significant amount of institutional power due to their sheer numbers. This allows them to more effectively push for their agenda in a negotiation at the bargaining table (Barnett \& Duvall 2005). Panke (2012) specifies some of these institutional structures, such as chairing meetings and setting the agenda, that allow states to influence the outcome of a negotiation. Relatedly, small states often band together in coalitions and then vote in a block; thus, while small states lack bargaining power individually, they are able to have significant power collectively (Long 2017). Coalition building is particularly important in negotiations that rely on majority voting because they have the numerical advantages that they need to successfully advocate for their policy preferences (Panke 2012). 
Again, institutional power is limited beyond the negotiation table. Because small states have a significant amount of collective power in terms of voting, they can more easily block treaties that run counter to their preferences than larger states. Thus, if large states wish to change the status quo, I argue, they must meet certain conditions to get these states to buy in to the treaty and, as such, they can use their institutional power to push for agreements that meet their needs and thus are widely ratifiable. However, there are some limitations to this power. Smaller states can use their institutional power to change the status quo over the objections of more powerful states. However, because such power does not extend beyond the negotiation, powerful states will largely not ratify the treaty. This argument leads to the following hypothesis.

Hypothesis 2: When small states hold significant institutional power, it is more likely that the resultant treaties will be poorly ratified. When small states do not hold significant institutional power, it is less likely that the resultant treaty will be ratified.

Given the power dynamics asserted in Hypothesis 2, it is important to note that this is not an argument about small states being rule-takers rather than rulemakers. Rather, it argues that small states will make rules in international law, but that others will likely not accept those rules. Such agreements, however, can still have valuable political effects for small states (Western et al. 2019). Additionally, this account places part of the explanation for widely ratified agreements on small states because when they have demands that are closer to the status quo, they can ensure that the agreement will have their support. Thus, they can ensure that a treaty will be widely ratifiable.

The previous factors are all "intrinsic" to the negotiation in that they matter at the bargaining table, but may have limited influence beyond it. Additionally, there are "extrinsic" sources of power that can influence the decision to ratify, but which are not limited to the bargaining table. Extrinsic bargaining power is derived from factors external to the negotiation. It captures a state's ability to use side payments, issue linkage, coercion, promises, or persuasion as tools of influence. This type of power is important because a state that has the ability to use these strategies can influence other states' behavior both at and beyond the negotiation table. States can therefore use extrinsic power to get their interests reflected in the bargaining outcome, as well as to get other states to ratify the agreement that is reached. When states with "intrinsic" power, such as chairing a meeting, also have "extrinsic" power, they are able to use their influence both at the negotiation table and beyond it. This argument leads to the final hypothesis. 
Hypothesis 3: When extrinsically powerful states also hold institutional power, the resultant treaties are more likely to be widely ratified than when they do not.

Bargaining power shapes negotiations in powerful ways and, in general, this argument is consistent with the arguments in the literature. However, it also points out that there are some disconnects between how this process is manifest at the bargaining table and how it is manifest away from it. Importantly, it argues that agreement at the bargaining table does not necessarily translate into the ratification phase. Instead, it finds that there are significant differences in agreements that make it through the bargaining process and therefore making it past the negotiation table is an important step but by no means does it ensure more substantial success.

\section{Research Design}

This project uses a mixed methods research design by conducting both a statistical analysis and qualitative case studies which allow the strengths and weaknesses of each approach to be balanced. In doing so, it provides stronger inferences (Johnson et al. 2007). Specifically, quantitative methods allow for inference over a wide range of cases and thus it is possible to make broader generalizations from such studies. The primary weakness of statistical analyses is that quantification lends itself to variables that are easily measured and, indeed, in this study the ways in which the hypotheses are evaluated are highly abstracted from the theoretical concepts relevant to negotiations (Hopmann 2002). Qualitative research allows for considerably more detail and understanding of processes but it is often unclear how representative cases are of larger patterns. This research will first cover the quantitative conclusions before providing more details of what such differences in negotiations look like in practice in two pairs of qualitative case studies.

\section{Measuring Ratification Rate and Its Determinants}

To analyze my theory, I need a set of treaties that are open to the same number of states to ratify and are negotiated under similar institutional rules. For this, I relied on the United Nations Treaties Series, which is a record of treaties deposited with the United Nations. From this database, I exclude treaties that were negotiated prior to 1945 , amendments to treaties created under the League of Nations, treaties that create intrinsic international organizations, non-universal treaties, and treaties focusing on commodities. I include 
amendments to a treaty can only be signed by parties of the original agreement in my sample because all states could theoretically ratify them if they ratify the original treaty. Based on these criteria, I coded 155 treaties, protocols, and amendments (see Appendix S1). ${ }^{10}$

My primary dependent variable is the ratification rate as of the end of 2014, which is defined as the ratio of state parties to potential parties - defined as 206, the number of UN member states, UN observer states (Holy See and Palestine), and small island nations (i.e., Cook Islands, Nauru, and Niue) - that may (and do) ratify international agreements. While UN membership has varied over time, all states are currently eligible to ratify any universal agreement. Indeed, new states in the system often ratify international agreements shortly after independence. South Sudan gained independence in 2011 and ratified the UN Convention to Combat Desertification in April 2014. Similarly, Palestine, which was recognized as an observer state in 2012, ratified several key human rights treaties in April 2014, including one that had been open for ratification for eight years and one that had been open for ratification for 66 years. This variable is scaled so that theoretically a value of zero means that no states have ratified, while a value of one means that all states have ratified.

Based on Fig. 2, it is clear that that the ratification rate is skewed right, indicating that many treaties have low participation rates. Indeed, a quarter of treaties are ratified by fewer than twenty percent of states and sixty percent of treaties are ratified by fewer than fifty percent of states. Indeed, only eleven percent of treaties have been ratified by more than ninety percent of states. These data show that near universal treaties are rare; however, treaties with high ratification rates tend also to be those that attract most academic interest and reflect the preferences of powerful, Western states. This information is useful as scholars have recently diagnosed specific treaties with "participation problems" (Chapman \& Chaudoin 2013; Ruhs 2013); however these diagnoses are made without reference to a baseline of treaty participation. Moreover, it extends the findings of Von Stein (2018) as it shows that low ratification occurs across a broader range of international treaties.

The theoretical arguments identify three different hypotheses. The first hypothesis states that treaties that have more consensus built for them in the negotiation process are more likely to be widely ratified. Although this concept is difficult to measure, one indicator of consensus can be determined by evaluating whether or not negotiators sign the agreement that they helped to negotiate. Bradley (2012) posits that when an executive signs a treaty it is a signal that she is satisfied with the negotiation process and the resultant treaty. Moreover,

10 In the supplementary material to this article, online at: 10.6o84/mg.figshare.11897916, Appendix S1. 


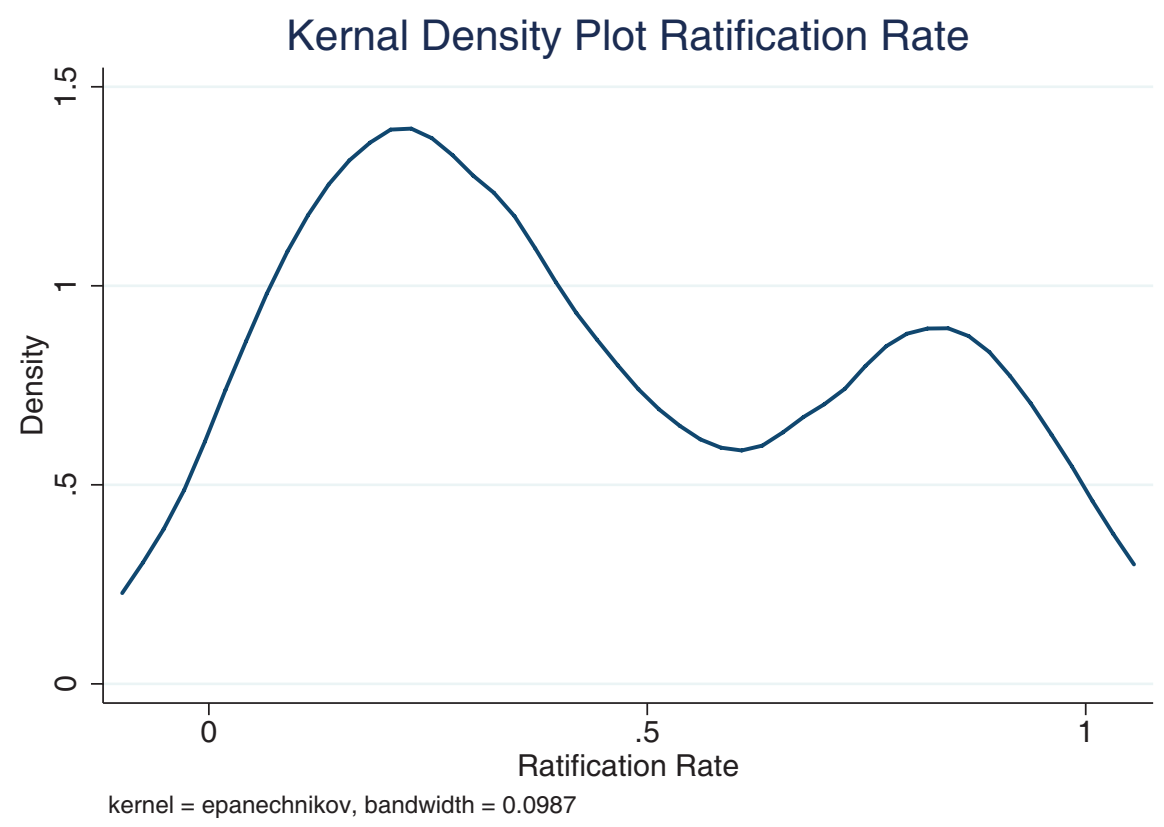

FIGURE 2 Ratification rate density

the period during which states can sign a treaty is limited, which indicates that signing reveals satisfaction based on the actual negotiation process from the regime that negotiated the agreement (Bradley 2012). Moreover, Cole (2009) and Elsig and Milewiscz (2017) find that signature is distinct from ratification and states sign for different reasons than they ratify, thus this variable is distinct from the dependent variable.

The second and third hypotheses posit that institutional power influences ratification rate. Although there are numerous sources of institutional power, one important source is chairing the negotiation (Tallberg 2010). Thus, in evaluating these hypotheses I focus on characteristics of chairs in the negotiation process. The second hypothesis argues that treaty negotiations that are headed by less powerful states are less likely to be ratified than treaties chaired by other states. To evaluate this argument, negotiations are coded as to whether they are headed by a G-77 state. Although there are many definitions of small states, and indeed some definitions of small states would include developing countries, the mechanisms underlying this hypothesis specify that such states have significant potential for collective power. Given the numerical superiority of the G-77 group as opposed to other comparable blocs and given that this group does act collectively in international negotiations (Freeman 2017), they are the most relevant group to evaluate. 


\begin{tabular}{lcc}
\hline & Model 1 & Model 2 \\
\hline Negotiator signing rate & 3.25 & 2.99 \\
& $(0.35)$ & $(0.42)$ \\
G-7 state & 0.10 & 0.17 \\
& $(0.23)$ & $(0.23)$ \\
G-77 state & 0.33 & 0.46 \\
& $(0.23)$ & $(0.25)$ \\
Constant & -1.87 & -1.65 \\
& $(0.17)$ & $(0.26)$ \\
Issues & No & Yes \\
Observations & 138 & 138 \\
AIC & 129.1 & 154.3 \\
\hline
\end{tabular}

The third hypothesis argues that treaties are more likely to be widely ratified when powerful states have institutional power than when they do not. Although there are numerous indications of power, financial wealth increases the power of states. To evaluate this concept, I include a measure of whether a treaty negotiator was a member of the G-7 (Canada, France, Germany, Italy, Japan, United Kingdom, and the United States) as these states have developed economies and financial ties that may further enable them in the negotiation process. The baseline against which these variables are compared are all other chairs cases where multiple chairs were present over the course of the negotiation.

\section{Statistical Findings}

Because treaty ratification is a ratio variable, and thus bounded between $o$ and 1, I use a generalized linear model using the binomial family and a logit link.11 The results of the statistical analysis are found in Table 1 above. Model 1 includes only the main variables. Model 2 controls for the treaty issue area as defined by the United Nation Treaty Series.

11 Appendix S1, available online at: 10.6084/mg.figshare.11897916 does account for additional factors that may influence ratification rate and shows that the conclusions presented in this table are consistent when controls are included. 


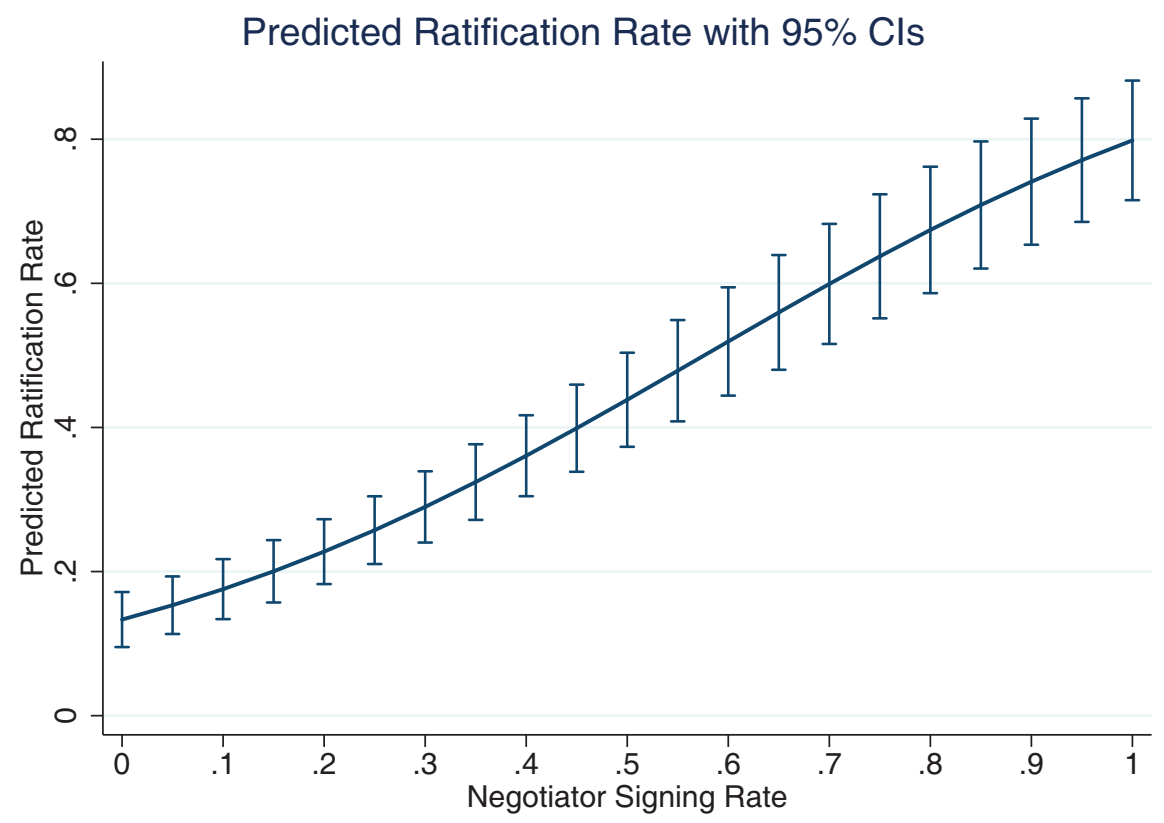

FIGURE 3 Marginal effects of negotiator signing rate on treaty ratification rate

The statistical findings yield mixed support for the theoretical argument. ${ }^{12}$ Hypothesis 1, which posits that treaties that build more support during the negotiation process are ratified at higher rates, is supported in this analysis. Ratification rate increases as the rate at which negotiators sign a treaty increases. This finding is not only statistically significant, it is substantively meaningful. Treaties a standard deviation below the mean negotiator signing rate have an expected ratification rate of 0.25 whereas states at the mean level of negotiator support have an expected ratification rate of approximately $0.47 \cdot{ }^{13}$ This substantive impact is further illustrated in Fig. 3, which shows the substantive relationship between negotiator signing rate and treaty ratification. This finding also supports the larger argument, which is that viewing negotiation success simply by whether an agreement is created masks a significant amount of variation in the treaty creation process. Treaties exit the negotiation process with varying levels of support among negotiators and this variation is strongly correlated with the ratification phase of the negotiation. One limitation of these findings is that it is difficult to determine the source of the

\footnotetext{
12 These models are run in Stata 15.1.

13 These figures are 0.25003 and .46788.
} 
consensus as it could be persuasive argumentation or it could be an alignment of preferences. In either case, however, creating an agreement that negotiators will sign onto is strongly related to a treaty's success in the ratification stage.

The statistical evidence does not support the second and third hypotheses, however. These hypotheses posit that the power of states in positions of institutional power shapes ratification rate. There is not a statistically significant relationship between negotiations chaired by a single G-7 or G-77 country compared to negotiations chaired by other states or multiple states. In Model 2, the coefficient for G-7 states is not statistically significant at 0.05 level, but it is statistically significant at the o.1o level. Even here, the magnitude is fairly small. Thus, based on this evidence, there is no evidence to indicate that chairing as a form of institutional power influences ratification rate.

The quantitative evidence presented in this section provides important information about the treaty creation and ratification process. The primary contribution is highlighting the extent to which treaty ratification varies across different international agreements. Although the treaty ratification literature focuses on widely ratified agreements, these treaties are not representative of treaties more broadly. As such, it is necessary to reassess why states ratify in ways that can extend beyond these popular agreements. The secondary contribution highlights that treaties leave the negotiation table with considerable variation in the support that they have among negotiators and that this variation is strongly associated with the ratification phase of the agreement. This broad-strokes view of negotiations reveals important patterns in the data, namely that what occurs at the bargaining table likely casts a shadow beyond the negotiation phase. The following section explores different negotiations and demonstrates that consensus formation and power play different roles in poorly-ratified and well-ratified treaties.

\section{What Happens at the Negotiation Table}

Negotiation processes differ substantially even when they culminate with a treaty. These differences are likely to influence the support that the treaty can receive in terms of ratification. To evaluate these arguments, I evaluate two pairs of treaties; each pair contains a treaty that is widely ratified and one that is poorly ratified. The evidence presented here supports the arguments developed in the theoretical section.

Mercenaries vs. Hostage-Takers: Bargaining Power and Ratification

This section evaluates two criminal treaties created at the UN: the International Convention against the Taking of Hostages (hereafter referred to as the 
"Hostages Treaty") and the International Convention Against the Recruitment, Use, Financing, and Training of Mercenaries Convention (hereafter referred to as the "Mercenaries Treaty"). In both cases states' preferences differed on how to address these crimes, but in the case of the Hostages Treaty states created a widely ratifiable treaty, whereas during the Mercenaries Treaty negotiations they did not.

Two similarities of these agreements are particularly noteworthy. First, these treaties share similar structures and provisions. Each agreement begins with a definition of the act which is the focus of the treaty (United Nations 1979b, Article 1, 1989b, Article 1 and 3). States are required to define the act as criminal (United Nations 1979b, Article 2, 1989b, Article 5). States are required to cooperate to prevent the crime from occurring (United Nations 1979b, Article 4, 1989b, Article 6). If an accused criminal is found on the territory of a party to the treaty, that state is required to either extradite the alleged offender or refer the case for prosecution (United Nations 1979b, Article 8, 1989b, Article 12). Parties are also required to cooperate in any trial by providing evidence (United Nations 1979b, Article 11, 1989b, Article 13). Finally, in both agreements, states are required to communicate the outcome of such a trial and other relevant information with the state of the national being tried, the United Nations Secretary General and/or other interested parties (United Nations 1979b, Article 6 and 7 , 1989b, Article 8 and 10). These similarities are not coincidental as direct references to the Hostages Treaty were made during the Mercenaries Treaty negotiations and negotiators purposefully pulled provisions from the earlier, and more successful, treaty (United Nations 1983; 1985b).

Second, both agreements were negotiated around the same time and, as such, Cold War dynamics and relations between Third World states and Western states are held relatively constant across both negotiations. This is important because in both negotiations coalitions formed around Cold War blocs and the negotiation focused on the different preferences of Third World states and Western states.

Importantly, these treaties have different ratification rates. Fig. 4 illustrates the number of states that have ratified each agreement. States have steadily ratified the Hostage Treaty since it was open for ratification over 35 years ago. While there is a spike in ratification around the twenty three-year mark that is likely attributable to states ratifying terrorism-related treaties in the aftermath of $9 / 11$, the events do not drive the differences in ratification. The gap existed before the attack; thus, even without a surge in ratification, the Hostages Treaty would be more widely ratified than the Mercenaries Treaty. Moreover, the steady increase in ratification that occurred prior to the attacks continued after the dramatic upswing in the early 200os, indicating continued support 


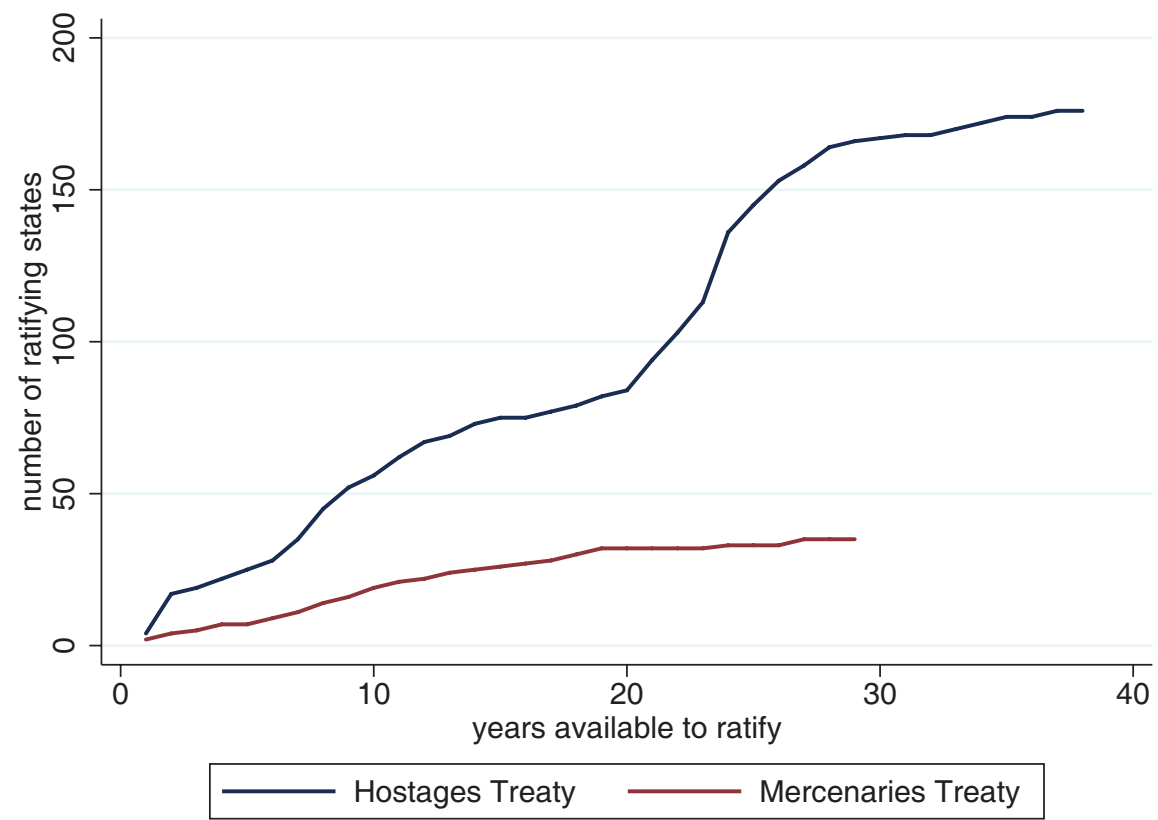

FIGURE 4 Number of ratifying states to the Hostages Treaty and Mercenaries Treaty

after the attacks themselves were less salient. In contrast, the Mercenaries Treaty has a low ratification rate that has leveled off over time.

The spark for the negotiations of the Hostages Treaty was high profile hostage-taking actions in Western states and, as such, these states led the creation of the international agreement (Blumenau 2014; Lambert 1990; Stephens 2004). During the Hostages Treaty negotiations Western states led the international agenda. The Federal Republic of Germany (FRG) wrote the initial draft of the agreement and it widely appealed to most states, but Western states in particular. Third World states, similarly, had some intrinsic power in the Hostages Treaty negotiation, which derived from their numerical superiority over Western states. They were able to use this advantage to advocate for their preferences in addressing concerns, such as territorial integrity and hostagetaking by nationalist groups.

The resulting relatively widespread appeal of the agreement is evidenced in the following ways. First, in the negotiations, states did not threaten to not ratify the treaty. Second, negotiators stressed that it was possible to create an agreement that could get widespread support. For example, the Algerian representative emphasized that greater discussion was necessary to ensure that the treaty "could be ratified by the largest possible number of states" (United Nations 1977: 31). This illustrates that negotiators foresaw the possibility of widespread ratification and worked to have the treaty meet that standard. 
States compromised on the issue of territorial integrity during Hostage Treaty negotiations (Blumenau 2014). This issue was driven by Israel's actions in Entebbe to rescue hostages. Syria, Tanzania, Algeria, and other African and Arab states proposed a provision that would forbid states from threatening to use force against another state and forbid the violation of another state's sovereignty to ensure that hostages were rescued. While other states did not dispute the importance of territorial integrity, they argued that these provisions are established by the United Nations Charter and did not need to be included within the treaty itself (United Nations 1979a). The compromise states: "Nothing in this Convention can be construed as justifying in any manner the threat or use of force or any interference whatsoever against the sovereignty, independence or territorial integrity of peoples and States, under the pretext of rescuing or freeing hostages." (United Nations 1977: 112). This compromise allows states to address breaches to the peace and it can accommodate views that justify intervention and those that forbid it (Lambert 1990). It is also purposefully vague which means it can accommodate different interpretations.

Despite major areas of contention, it is important to consider that the negotiators were able to compromise on major issues. These solutions addressed the concerns of various actors while achieving the ultimate goal by creating an agreement that would close the legal loophole of hostage-taking during peacetime. These compromises show that states were able to persuade others to accept positions that could generate widespread support.

There is additional evidence that argumentation was successfully used in the Hostages Treaty negotiations. Third World states were reluctant to accept the FRG proposal and wanted the Secretary General to propose an alternative based on the suggestions that states had put forward. However, this controversy waned after the FRG negotiator, Baron von Wechmar, made a statement clarifying the legal principles that the treaty was based on and reaffirmed that it was his state's proposal. This statement alleviated concerns from Third World states. For example, Mr. Bouayad-Agha of Algeria stated that he:

...thanked the representative of the Federal Republic of Germany for the explanations he had given on the draft. It was gratifying to be able to verify that the document really belonged to the Federal Republic of Germany and not to the United Kingdom or the United States of America and also that it was merely one document among many others (United Nations 1977: 48).

After this statement there was a general agreement to use the FRG draft moving forward. 
In contrast, Western states had little intrinsic bargaining power in the Mercenaries Treaty negotiations. Although "all delegations condemned the use of mercenaries" (United Nations 1981: 6) and there was general agreement that mercenaries should not be used (United Nations 1983), there were significant differences in the degree to which states argued that international law was needed to address the issue. The ostensible consensus that international law was necessary occurred in part because Third World states successfully used "lock-in" tactics such that Western states could not successfully argue for provisions that would protect their citizens who were employed as mercenaries. This strategy, however, masked important areas of disagreement, namely the object and purpose of creating a treaty on mercenaries, keys aspects of the definition of a mercenary, and obligations of states whose citizens were mercenaries. These disagreements were most clearly evident between Western and Third World states. Western states did not want a treaty to curb the use of mercenaries, while Third World states wanted an agreement that prohibited mercenaries from being used against them.

Western states that had used mercenaries and those whose citizens had engaged in mercenary activities did not want significant changes from the status quo (Taulbee 1985). These states preferred using domestic laws to regulate their own citizens' engagement in foreign conflicts. Moreover, these states, such as France, the United States, and the United Kingdom, might have had mercenaries used against their interests, but mercenaries were not a threat to these states' territorial integrity in the same way that it was for Algeria or Nigeria. It was widely believed that Western states would not ratify the ultimate agreement and they lacked a numerical advantage to push the agreement closer to their preferences. Taulbee (1985:364) noted "many governments, including the United States, may still decline to ratify the [Mercenaries Treaty], preferring the flexibility of the status quo."

Moreover, Third World states, particularly Nigeria, which drafted the original agreement, led the negotiation process, lacked extrinsic bargaining power, and thus were unable yield bargaining power beyond the negotiation table. Interestingly, these states that led the negotiation process were not themselves early adopters of this treaty.

Third World states wanted a treaty that prevented Western states and interests from intervening in their affairs and wanted strict punishments for individuals, corporations, and states complicit in such actions. Western states proposed an agreement that would ensure mercenaries would be legally accountable for the crimes they commit but was far more limited. The interests of Western states are discounted in the final agreement. Third World states instead emphasized substantive changes to move the agreement as near to their 
preferred position as possible because although widespread ratification was not realistic, they could codify their preferences in international law nonetheless.

Third World states were forced to concede on some of their more extreme demands, such as making states liable when their nationals engage in mercenary activities and allowing states to sue if others did not keep their commitments. But, in these areas, Western states were unwilling to concede and their arguments that these provisions were incongruent with international law are reflected in the fact that these provisions are omitted from the treaty. While the treaty finally made it through the negotiation phase, the significant contention and lack of genuine support for the treaty had lasting impacts.

These two cases combined provide compelling evidence that supports the theoretical argument. Differences in extrinsic bargaining power likely explains some of the disparity in ratification between these two agreements. When extrinsically powerful states dominated the international agenda, they create an agreement that could be (and has been) widely ratified. This was not only due to extrinsic power but also due to the intrinsic power of Third World states that were able to successfully push the agreement closer to their own preferences so they could eventually ratify the treaty. However, when states with only intrinsic power led the Mercenaries Treaty negotiation, they pushed their agenda and created an agreement that encapsulated their preferences but was unable to be widely ratified. In particular, the use of lock-in strategies masked disagreement about the treaty which carried through to the ratification phase. Moreover, the states leading the Mercenaries Treaty negotiations lacked power to convince others to ratify the ultimate agreement. Thus, although international law about mercenaries reflects the preferences of Third World states, low ratification means that this victory is hollow. International laws on hostage taking, however, are far more substantial due to widespread ratification.

\section{Migrant Rights vs. Human Trafficking: Bargaining Power and Ratification}

The second set of cases focuses on migration-related issues and specifically looks at the Convention on the Protection of the Rights of All Migrant Workers and Their Families (hereafter referred to as the "Migrant Rights Treaty") and the Protocol to Prevent, Suppress and Punish Trafficking in Persons, especially Women and Children (hereafter referred to as the "Trafficking Treaty"). Preferences differ across these negotiations as states have dissimilar preferences on voluntary migration and migrant rights due to the different costs and benefits of providing migrants rights. States share similar preferences on human trafficking, however. While few have ratified the Migrant Rights Treaty, many states have ratified the Trafficking Treaty. I discuss the similarities in greater detail below. 


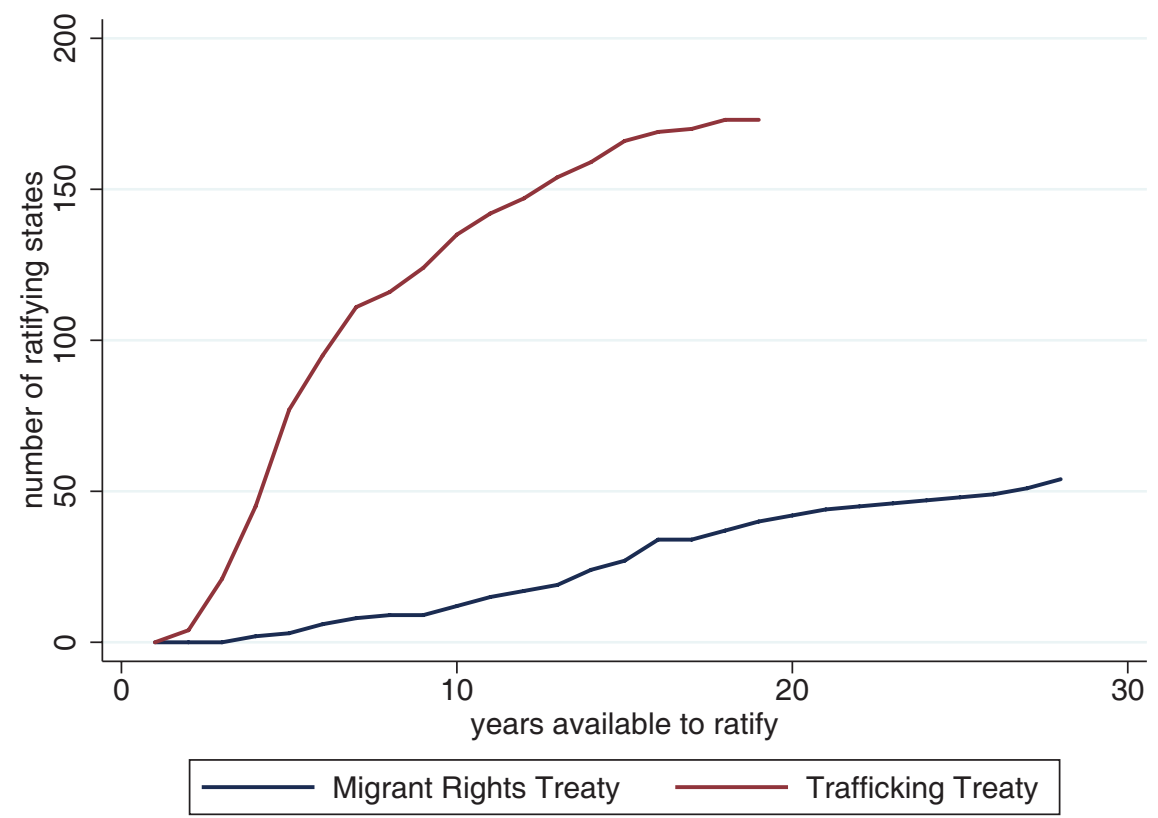

FIGURE 5 Number of ratifying states to the Trafficking Treaty and Migrant Rights Treaty

The most important similarity between these treaties is that they deal with the same broad issues, namely migrant exploitation and illegal migration. The Migrant Rights Treaty establishes basic human rights for migrant workers, but also calls on states to cooperate to prevent illegal immigration (United Nations 1990). The Trafficking Treaty stipulates that human trafficking is a crime that states should work to prevent, but calls on states to protect victims' rights (United Nations 2000). Despite having different classifications under the United Nations Treaty Series, as the Trafficking Treaty is a penal agreement and the Migrant Right Treaty is a human rights agreement, they deal with many of the same underlying issues making the cases as similar as possible. ${ }^{14}$ Fig. 5 shows that these treaties do have a wide disparity in ratification rate. The Trafficking Treaty was quickly and widely ratified whereas the Migrant Rights Treaty was not. Indeed, the disparity in ratification is so severe that they came into effect in the same year despite the Migrant Rights Treaty having been

14 One problem with comparing the Migrant Rights Treaty to other human rights agreements is that the treaty has one crucial difference in that it regulates the state's actions vis-a-vis non-citizens, whereas all other human rights agreements focus primarily on the relationship between citizens and the state (Money, Lockhart \& Western 2016) 
created some ten years earlier. To this day, ratification of the Migrant Rights Treaty remains low. Consequently, migrant rights are not well protected under international law, whereas states have widely agreed to cooperate on human trafficking issues. Again, for these treaties there is a significant disparity in the extrinsic power of the states advocating for their creation.

The Migrant Rights Treaty was led by migrant-sending states that wanted their own citizens to be protected in migrant-receiving countries (Lonnroth 1991). Mexico and Morocco led the campaign to create the Migrant Rights Treaty. Mexico wrote the initial draft treaty and advocated for a strong agreement that would promote migrant rights as human rights. In particular, Mexico was concerned with protecting undocumented migrant rights and worker's rights. Migrant-sending states used their intrinsic bargaining power to advance a treaty that codified sending state preferences in international law (United Nations 1985a). At the UN, the decision to create a treaty rests with the General Assembly where each state has an equal voice; the international agenda is set by majority vote. Thus, intrinsic bargaining power rests on having a majority of states that will support the agenda. Such power often gives developing states, who have a numerical majority, intrinsic bargaining power and the ability to shape the international agenda because their strength rests in numbers (Panke 2012). Yet migrant-sending states lacked extrinsic bargaining power. Migrant-sending states tend to be poorer and less developed than migrant-receiving states and they are unable to effectively tie rewards or punishment to other states' decision to ratify. Consequently, migrant-sending states had intrinsic power in the negotiation, whereas migrant-receiving states are largely wealthier and had extrinsic power in the negotiation.

During the Migrant Rights treaty negotiations there were explicit concerns about ratification due to a lack of support among negotiators. In the 1985 meeting of the Working Group, the FRG representative stated that the FRG would refrain from ratifying the convention because the treaty was too broad, inflexible, gave too many rights to undocumented migrants, and was generally unfavorable to FRG interests as a state of employment (United Nations 1985a). This sentiment was again reiterated in 1987 when FRG officials argued that it was unlikely that they would ratify and that the delegation was relieved when it was clarified that the "Convention would have legal force only for those States which became parties to it" (United Nations 1987: 54). The American and the FRG delegates also implied that ratification was not possible unless special considerations were made for implementation in federal states (United Nations 1989a: 38). Lonnroth (1991: 734) also found that among the negotiators there was a common belief that the United States would neither sign nor ratify the treaty. 
Moreover, immediately after the negotiations concluded and the treaty was sent to the United Nations General Assembly, Japan, Oman, and Australia, all of whom participated in the negotiations, publicly declared that they would not become parties to the treaty (Böhning 1991). While this may appear to be only a handful of states, these states are likely indicative of broader dissatisfaction among migrant-receiving states about the treaty and evidence that while these states ushered the treaty through the negotiation process, they were not genuinely persuaded of its merit.

That few states were willing to ratify the Migrant Rights Treaty was likely evident by the contention at the negotiation table. Much of the language in the treaty was arrived at only after significant debate and disagreement. For example, there were significant discussions about the definition of "property" (United Nations 1985c: 5), "migrant worker" (United Nations 1985c: 5) and "specified employment worker" (United Nations 1985c: 14). The degree of disagreement and contention was so clear that negotiators noted that agreement was unusual. For example, the Moroccan delegate stated that a provision protecting migrants from torture was "noteworthy because it had been provisionally adopted without objections or amendments" (United Nations 1982: 7)

In sharp contrast, migrant-receiving states, particularly the United States, led the creation of the Trafficking Treaty. The US voluntarily pledged $\$ 511$,ooo to support the development of the Convention on Transnational Organized Crime (United Nations 1998: 6). Moreover, the US, along with Argentina, ${ }^{15}$ initially proposed drafts to the committee, indicating American leadership on the issue (United Nations 2006). Additionally, preventing and punishing human trafficking was a major issue in American foreign policy agenda (Chuang 2006). In 200o, the United States passed a domestic anti-trafficking law, one element of which requires the State Department to publish an annual report on human trafficking in every country and grade states on their efforts to address trafficking. States that fail to improve face American sanctions. Consequently, this law provides states an additional incentive to ratify the Trafficking Treaty because it is noted in each state's report and is an easy step states can take to improve their rating (Chuang 2006). Thus, in addition to having intrinsic power to shape the negotiation, the states working on human trafficking also had extrinsic bargaining power to promote participation outside of the negotiation in the case of the Trafficking Treaty.

In the Trafficking Treaty, negotiators seemed to be aware that there was this potential for a widely ratifiable treaty and pursued compromises that would

15 The differences between the American and Argentinian drafts were resolved during the conference and a joint proposal was put forward. 
enable an agreement that could get widespread participation. There was an emphasis on seeking common ground and using contributions from as many states as possible to ensure that the treaty could be widely adopted (United Nations 2006: xvi). In the negotiations there was an emphasis on building consensus on each provision such that even if states disagreed, they could ultimately support the agreement. For instance, when states did not entirely agree on provisions in the treaty they noted that they would confirm these disagreements on ratification through the use of reservations or interpretative statements (United Nations 2006: 346).

In both treaties, states that led the creation process had intrinsic bargaining power. The Trafficking Treaty also had the support of states with extrinsic bargaining power. These states, particularly the United States, had the ability to influence others to ratify the treaty. However, in the Migrant Rights Treaty negotiations, the states leading the negotiation process chose positions that made the agreement unratifiable for many states. Extrinsic bargaining power can promote ratification, but it requires that states are willing and able to use this ability; in the case of these treaties the United States was able and willing to push for the ratification of the Trafficking Treaty, whereas the proponents of the Migrant Rights Treaty were not able to do the same.

\section{Discussion}

Comparing these four negotiations, it is possible to gain a better understanding of the role of bargaining power in the negotiation process. Where extrinsically powerful states lead negotiations, they create agreements that are quickly and widely ratified. In contrast, when extrinsically powerful states oppose the creation of the agreement ratification, difficulties are foreseen before the agreement leaves the negotiation table. Under such circumstances, states create an ineffectual agreement that specifies their preferences, but that will not be widely ratified in practice. Although these results are not born out in the statistical analysis, one reason for this may be that the role of extrinsic power is complex and thus the blunt quantitative measures do not adequately capture the nuances seen in the case studies.

While extrinsic bargaining power seems to influence ratification rate, the role of intrinsic bargaining power remains significant in shaping the content of the agreement and ratification in a counterintuitive respect. In both the Hostages Treaty and the Mercenaries Treaty negotiations, Third World states were able to band together to push the agreement closer to their own preferences. In the Hostages Treaty negotiations this meant a treaty nearer to the 
status quo than Western states whereas in the Mercenaries Treaty negotiations this meant a treaty that Western states would not ratify. Perhaps this fact explains the somewhat slow uptick in ratification for the Hostages Treaty. This also may explain why it is still nowhere near universal even though it has been more widely adopted than the Mercenaries Treaty. Similarly, migrant-sending states were able to get important concessions from the migrant-receiving states during the Trafficking Treaty negotiations that meant the agreement could be widely ratified.

These cases show that there are significant differences in the extent to which states are willing to advocate for their policies abroad. The Hostages Treaty, while created by states with extrinsic bargaining power, was not as strongly advocated for as the Human Trafficking Treaty. Thus even among agreements that have powerful advocates, the willingness of these advocates to push for ratification can vary and this variation in turn can effect ratification rate. Perhaps such factors help to explain the relatively weak statistical findings of the paper in regard to extrinsic power; having an extrinsically powerful advocate for an agreement may be necessary but insufficient to support widespread ratification. At the very least these cases show that the differences in intrinsic and extrinsic bargaining power are crucial because the positions of states with intrinsic and extrinsic power shape the possibility for a widely ratifiable agreement.

These cases also show that there are strengths and weaknesses of argumentation as a negotiation strategy. In both the Mercenaries Treaty and the Migrant Rights Treaty negotiations, those seeking to create a strong international agreement relied on moralistic arguments and ultimately the states that opposed them were not able to successfully argue against them. Yet beyond the negotiation table, these lock-in strategies were not effective because they did not promote ratification. Thus, these findings illustrate that wins at the negotiation table do not necessarily translate beyond it. To the extent that creating a widely ratifiable treaty is the goal of a negotiation, more care should be taken to ensure that negotiators genuinely support the treaty rather than merely assent to allowing the treaty through the negotiation process.

\section{Conclusion}

Negotiation success is more complex than whether or not states reach an agreement at the bargaining table. By moving the definition of success from the negotiation table to the ratification phase, it is possible to see which 
strategies, arguments and compromises are genuinely effective at promoting agreements and which are less successful. For instance, while lock-in strategies appear to be effective at the negotiating table, their success beyond seems limited as states can easily avoid being locked in during the ratification phase. Thus, strategies that might be effective in reaching an agreement might hinder the ratification phase of the negotiation process.

These findings further complicate our understanding of the enforcement phase of a treaty and in particular how this phase matters in treaty negotiations. The enforcement phase has been framed as key to the negotiation process (Fearon 1998). The rational design school argues that treaties are bargained with a particular focus on the enforcement (Koremenos, Lipson \& Snidal 2001). Similarly, the managerial school argues that enforcement depends on the development of international norms that requires states to be considered in good standing (Chayes \& Chayes 1998). Yet the case studies reveal that the enforcement stage can be heavily discounted at times, which suggests new reasons that states create treaties. One reason that may be plausible is that treaties benefit a domestic constituency (Western et al., 2019). Yet another reason may be that creating a treaty is an end in and of itself and that treaties provide symbolic victories for states that want to change the international order to reflect their views but lack the power to influence more powerful states. In either case, these findings complicate the picture of what international law is, how it is negotiated, and indeed why it is created.

\section{References}

Blumenau, Bernhard (2014). "The Other Battleground of the Cold War: The UN and the Struggle against International Terrorism in the 197os." Journal of Cold War Studies 16, 1: 61-84.

Böhning, Roger (1991). "The ILO and the New UN Convention on Migrant Workers: The Past and Future." International Migration Review 25, 4: 1-13.

Box-Steffensmeier, Janet M. and Brad S. Jones (2004). Event History Modeling: A Guide for Social Scientists. Cambridge: Cambridge University Press.

Bradley, Curtis (2012). "Treaty Signature," in Duncan B. Hollis, editor, The Oxford Guide to Treaties. Oxford: Oxford University Press.

Chapman, Terrence L. and Stephen Chaudoin (2013). "Ratification Patterns and the International Criminal Court." International Studies Quarterly 57, 2: 400-409.

Chayes, Abram and Antonia H. Chayes (1998). The New Sovereignty. Cambridge: Harvard University Press. 
Christol, Carl Q. (1985). "The Moon Treaty Enters into Force." American Journal of International Law 79, 1: 163-68.

Chuang, Janie (2006). “The United States as Global Sheriff: Using Unilateral Sanctions to Combat Human Trafficking." Michigan Journal of International Law 27, 2: 441-494.

Cole, Wade M. (2005). "Sovereignty Relinquished? Explaining Commitment to the International Human Rights Covenants, 1966-1999." American Sociological Review 70, 3: 472-495.

Cole, Wade M. (2009). "Hard and Soft Commitments to Human Rights Treaties, 1966-200o." Sociological Forum 24, 3: 563-588.

Dembling, Paul G. and Daniel M. Arons (1967). "The Evolution of the Outer Space Treaty." Journal of Air Law and Commerce 33: 419-56.

Dimitrov, Radoslav S., Detlef F. Sprinz, Gerald M. Digiusto and Alexander Kelle (2007). "International Nonregimes: A Research Agenda." Politics, Languages \& International Studies 9, 2: 230-258.

Dluhosch, Barbara and Nikolai Ziegler (2011). "The Paradox of Weakness in the Politics of Trade Integration." Constitutional Political Economy 22, 4: 325-54.

Elsig, Manfred and Karolina Milewicz (2017). "The Politics of Treaty Signature: The Role of Diplomats and Ties That Bind." International Negotiation 22, 3: 521-543.

Fearon, James D. (1998). "Bargaining, Enforcement, and International Cooperation." International Organization 52, 2: 269-305.

Finnemore, Martha and Kathryn Sikkink (1998). "International Norm Dynamics and Political Change." International Organization 52, 4: 887-917.

Freeman, Dena (2017). "The Global South at the UN: Using International Politics to Re-Vision the Global." The Global South 11, 2: 71-91.

Goodliffe, Jay and Darren Hawkins (2006). "Explaining Commitment: States and the Convention against Torture." The Journal of Politics 68, 2: 358-371.

Hill, Daniel W. (2016). "Avoiding Obligation: Reservations to Human Rights Treaties." Journal of Conflict Resolution 6o, 6: 1129-58.

Hopmann, P. Terrence (2002). "Negotiating Data: Reflections on the Qualitative and Quantitative Analysis of Negotiation Processes." International Negotiation 7: 67-85. Hugh-Jones, David, Karolina Milewicz and Hugh Ward (2016). "Signaling by Signature: The Weight of International Opinion and Ratification of Treaties by Domestic Veto Players." Political Science Research and Methods 6, o1: 15-31.

Jaksetic, Emilio (1978). “The Peaceful Uses of Outer Space: Soviet Views." The American University Law Review 28: 483.

Janusch, Holger (2016). "The Breakdown of International Negotiations: Social Conflicts, Audience Costs, and Reputation in Two-Level Games." International Negotiation 21, 3: 495-520. 
Johnson, Burke R., Anthony J. Onwuegbuzie and Lisa A. Turner (2007). "Toward a Definition of Mixed Methods Research." Journal of Mixed Methods Research 1, 2: $112-33$.

Keohane, Robert (1984). After Hegemony: Cooperation and Discord in the World Political Economy. Princeton: Princeton University Press.

Koremenos, Barbara, Charles Lipson and Duncan Snidal (2001). "The Rational Design of International Institutions." American Journal of Political Science 55, 04: 761-799.

Lambert, Joseph J. (1990). Terrorism and Hostages in International Law: A Commentary on the Hostages Convention 1979. Cambridge: Cambridge University Press.

Long, Tom (2017). "Small States, Great Power? Gaining Influence through Intrinsic, Derivative, and Collective Power." International Studies Review 19, 2: 185-205.

Lonnroth, Juhani (1991). "The International Convention on the Rights of All Migrant Workers and Members of Their Families in the Context of International Migration Policies: An Analysis of Ten Years of Negotiation." International Migration Review 25, 4: 710-736.

Mau, Stephen D. (1984). "Equity, the Third World and the Moon Treaty." Suffolk Transnat'l LJ 8: 221.

McKibben, Heather Elko (2015). State Strategies in International Bargaining. Cambridge: Cambridge University Press.

Milewicz, Karolina M. and Manfred Elsig (2014). "The Hidden World of Multilateralism: Treaty Commitments of Newly Democratized States in Europe." International Studies Quarterly 58, 2: 322-335.

Money, Jeannette, Sarah Lockhart, and Shaina D. Western (2016). "Why Migrant Rights Are Different Than Human Rights," in Gary P. Freeman and Nikola Mirilovic, editors, Handbook on Migration and Social Policy. Northampton, MA: Edward Elgar Publishing.

Narlikar, Amrita (2010). Deadlocks in Multilateral Negotiations: Causes and Solutions. Cambridge: Cambridge University Press.

Nielsen, Richard A. and Beth A. Simmons (2015). "Rewards for Ratification: Payoffs for Participating in the International Human Rights Regime?" International Studies Quarterly 59, 2: 197-208.

Odell, John S. (2000). Negotiating the World Economy. Ithaca: Cornell University Press. Odell, John S. (2009). "Breaking Deadlocks in International Institutional Negotiations: The WTO, Seattle, and Doha." International Studies Quarterly 53, 2: 273-299.

Panke, Diana (2012). "Small States in Multilateral Negotiations. What Have We Learned?" Cambridge Review of International Affairs 25, 3: 387-398.

Panke, Diana (2015). "Lock-in Strategies in International Negotiations: The Deconstruction of Bargaining Power." European Journal of International Relations 43, 2: $375^{-391 .}$ 
Putnam, Robert D. (1988). "Diplomacy and Domestic Politics: The Logic of Two-Level Games." International Organization 42, 3: 427-46o.

Ramsay, Kristopher W. (2011). "Cheap Talk Diplomacy, Voluntary Negotiations, and Variable Bargaining Power." International Studies Quarterly 55, 4: 1003-1023.

Risse, Thomas (2000). "Let's Argue!': Communicative Action in World Politics." International Organization 54, 1:1-39.

Risse, Thomas, Stephen C. Ropp and Kathryn Sikkink (1999). The Power of Human Rights: International Norms and Domestic Change. Cambridge University Press.

Risse, Thomas, Stephen C. Ropp and Kathryn Sikkink (2013). The Persistent Power of Human Rights: From Commitment to Compliance. Cambridge University Press.

Ruhs, Martin (2013). The Price of Rights. Princeton, NJ: Princeton University Press. Schelling, Thomas (1980). The Strategy of Conflict. Cambridge: Harvard University Press. Schneider, Christina J. (2011). "Weak States and Institutionalized Bargaining Power in International Organizations." International Studies Quarterly 55, 2: 331-355.

Simmons, Beth A. (2009). International Law in Domestic Politics. Cambridge: Cambridge University Press.

Smith-Cannoy, Heather (2012). Insincere Commitments: Human Rights Treaties, Abusive States, and Citizen Activism. Washington, DC: Georgetown University Press.

Song, Jennefer and Dale Whittington (2004). "Why Have Some Countries on International Rivers Been Successful Negotiating Treaties? A Global Perspective: Treaty Negotiations on International Rivers." Water Resources Research 40, 5. At: https:// doi.org/10.1029/2003WRoo2536.

Spence, Douglas Hamilton (2014). "Foreign Aid and Human Rights Treaty Ratification: Moving beyond the Rewards Thesis." International Journal of Human Rights 18, 4-5: 414-432.

Stephens, Tim (2004). "International Criminal Law and the Response to International Terrorism." UNS W Law Review: 454-481.

Tallberg, Jonas (2010). "The Power of the Chair: Formal Leadership in International Cooperation." International Studies Quarterly 54, 1: 241-65.

Taulbee, James L. (1985). "Myths, Mercenaries and Contemporary International Law." California Western International Law Journal 15: 339-363.

Underdal, Arild (1983). "Causes of Negotiation 'Failure'." European Journal of Political Research 11, 2: 183-95.

United Nations (1977). "Report of the Ad Hoc Committee on the Drafting of an International Convention against the Taking of Hostages." UN Doc A/32/39, April, 1-119.

United Nations (1979a). "Report of the Ad Hoc Committee on the Drafting of an International Convention Against the Taking of Hostages." UN Doc A/34/39, March, $1-33$. 
United Nations (1979b). "International Convention Against the Taking of Hostages." Treaties.Un.Org, December.

United Nations (1981). "Report of the Ad Hoc Committee on the Drafting of an International Convention Against the Recruitment, Use, Financing and Training of Mercenaries." A/36/43, January, 1-32.

United Nations (1982). "Summary Record of the 61st Meeting, 3rd Committee, Held on Thursday, 2 December 1982, New York.” A/C.3/37/SR.61.

United Nations (1983). "Report of the Ad Hoc Committee on the Drafting of an International Convention Against the Recruitment, Use, Financing and Training of Mercenaries." A/38/43.

United Nations (1985a). "Report of the Open-Ended Working Group on the Elaboration of an International Convention on the Protection of the Rights of All Migrant Workers and Their Families." A/C.3/40/1.

United Nations (1985b). "Report of the Ad Hoc Committee on the Drafting on an International Convention against the Recruitment, Use, Financing and Training of Mercenaries." New York.

United Nations (1985c). "Report on the Open-Ended Working Group on the Drafting of an International Convention on the Protection of the Rights of All Migrant Workers and Their Families." A/C. 3/40/6.

United Nations (1987). "Report of the Ad Hoc Committee on the Drafting of an International Convention Against the Recruitment, Use, Financing and Training of Mercenaries." A/C.3/42/6.

United Nations (1989a). "Report of the Open-Ended Working Group on the Drafting of an International Convention on the Protection of the Rights of All Migrant Workers and Their Families."

United Nations (1989b). "International Convention against the Recruitment, Use, Financing and Training of Mercenaries," December, 1-6.

United Nations (1990). "International Convention on the Protection of the Rights of All Migrant Workers and Their Families"

United Nations (1998). "Report Of The Informal Preparatory Meeting Of The Open-Ended Intergovernmental Ad Hoc Committee On The Elaboration Of A Comprehensive International Convention Against Organized Transnational Crime, Held At Buenos Aires From 31 August To 4 September 1998."

United Nations (2000). "Report of the Ad Hoc Committee on the Elaboration of a Convention against Transnational Organized Crime on the Work of Its First to Eleventh Sessions," November.

United Nations (2006). Travaux Préparatoires of the Negotiation for the Elaboration of the United Nations Convention against Transnational Organized Crime and the Protocols Thereto. 
Vlasic, Ivan A. (1967). "The Space Treaty: A Preliminary Evaluation." California Law Review 55, 2: 507-519.

Voeten, Erik (2001). "Outside Options and the Logic of Security Council Action." American Political Science Review 95, 4: 845-858.

von Stein, Jana (2018). "Exploring the Universe of UN Human Rights Agreements." Journal of Conflict Resolution 62, 4: 871-899.

Weiler, Florian (2012). "Determinants of Bargaining Success in the Climate Change Negotiations." Climate Policy 12, 5: 552-74.

Western, Shaina D., Sarah P. Lockhart and Jeannette Money (2019). "Does Anyone Care about Migrant Rights? An Analysis of Why Countries Enter the Convention on the Rights of Migrant Workers and Their Families." International Journal of Human Rights 23, 8: 1276-1299.

Wotipka, Christine M. and Kiyoteru Tsutsui (2008). "Global Human Rights and State Sovereignty: State Ratification of International Human Rights Treaties, 1965-2011." Sociological Forum 23, 4: 724-754. 